\title{
O "nó de pensamento" de Luis Miguel Nava: cenas, alegorias, corpos e memórias
}

\author{
Sandro Ornellas*
}

\section{Resumo:}

Leitura do poeta português Luis Miguel Nava (1957-1995) a partir de uma hipótese que se baseia na idéia de ser o seu discurso poético uma convergência das tendências abstrato-experimentais dos anos 1960 e mimético-referenciais dos anos 1970, uma síntese poderosamente pessoal, que articula esses contextos estéticos da poesia portuguesa imediatamente anterior à sua a conceitos como os de alegoria e de experiência e memória cultural.

\section{Palavras-chave:}

Luis Miguel Nava, Alegoria, Corpo, Experiência cultural, Poesia portuguesa contemporânea

\section{Duas formas de olhar}

Mais difícil fica estabelecer critérios geracionais para a produção artística e literária, quanto mais olhamos para o presente. Olhando para o passado, o horizonte para o qual voltamos nosso olhar é sempre mais restrito. A edição e montagem já foram em grande parte feitas. Escritores, poetas e artistas fortes assomam facilmente à vista, que se detém em seus pontos luminosos com bem menos trabalho. O esforço analítico fica por conta do abismo histórico que nos separa da assinatura desses autores. Na verdade, quanto mais recuamos no tempo, mais penosa a tarefa de coordenar uma determinada assinatura ao seu espaço e tempo de inscrição. Muitas vezes parece que elas flutuam acima do solo histórico, descoladas de todo e qualquer vínculo com o corpo da terra. Quando ocorre de não conseguirmos ou tentarmos empreender essa travessia histórica, também podemos encontrar pelo caminho pequenas pepitas

\footnotetext{
* Professor Adjunto de Literatura Portuguesa e Estudos Comparados de Literaturas de Língua Portuguesa do Instituto de Letras e do Programa de Pós-Graduação em Literatura e Cultura da Universidade Federal da Bahia (UFBA).
} 
anacrônicas, esquecidas nas malhas do tempo. Prontas para serem retiradas do limbo da história, são assinaturas que geralmente não dizem respeito ao seu próprio espaço e tempo, tendo sido inscritas fora do lugar apropriado. Mas exatamente porque "mudam-se os tempos, mudam-se as vontades" (CAMÕES, 2003, p. 284), elas ganham novo colorido e inscrição aos olhos sempre renovados dos leitores. Reorganizam as paisagens historiográficas e, muitas vezes, o próprio presente com a inclusão de novas assinaturas nos compêndios. Um diferente grau de dificuldade tem a história do presente. O olhar não precisa empreender a (im)possível travessia histórica para se desbaratar do anacronismo de uma mirada embriagada de atualidade. Seu globo ocular vibra com os mesmos fluxos que atravessam os autores. Fluxos semióticos. Fluxos históricos. Fluxos políticos. Fluxos eróticos. Fluxos poéticos. O delírio que impele à força de assinar por parte de uns se aproxima do que impele ao gesto de olhar por parte de outros. Ambos co-habitam o mesmo corpo histórico, o mesmo corpo territorial, e o movimento de aproximação agora depende de outro tipo de esforço. Deter o olhar que vibra incessantemente em função do movimento do seu campo de desejo, demasiado instável e vivo, é muitas vezes um esforço tremendo. A vontade em deixar-se conduzir pelos fluxos que atravessam $o$ campo é enorme. Historiar, nesse caso, confunde-se com mapear, cartografar o espaço. Controlar essa paisagem selvagem que é o presente dos fluxos confunde-se com a tarefa de conhecê-la. Há o risco de se confundir narcisicamente o próprio olhar com o campo de interesse desse desejo. Mas isso também faz parte das políticas que movem os corpos.

\section{A cena olhada}

É ponto comum entre seus comentadores: Luis Miguel Nava - apesar de ter lançado Películas, primeiro livro, em 1979 - não pode ser filiado diretamente à poesia produzida nos anos 1970 . É bom que se diga, aliás, antes de qualquer outra afirmação, que esse é um debate ainda quente e algo espinhoso, pois uma parte dos atores está bem viva e ativa. Os critérios que grande parte dos analistas do presente têm sacado para separar gerações têm sido o das décadas. Às vezes de forma mais rígida, às vezes de forma mais flexível. Difere este critério daqueles que o próprio Nava usou para demarcar gerações poéticas em Portugal depois de Fernando Pessoa. Para isso, ele usa a data da morte de Pessoa, 1935, e do simultâneo lançamento de La voyelle promise, livro escrito sintomaticamente em francês por Vitorino Nemésio. E escreve: "ser-nos-ia 
possível falar de dois grandes períodos da poesia portuguesa posterior a Fernando Pessoa (...): um de 1935 a 1960 e outro de 1961 a nossos dias" (NAVA, 2004, 193). Interessa-nos nessa percepção periodológica posta em exercício por Nava menos os critérios e mais a extensão dos períodos. Mais de trinta anos por cada geração. Diferentemente das análises hoje comuns - que muito se confundem com o tipo de jornalismo cultural de "urgência", que vive de fazer listas de "os melhores" e "os piores" do mês, do ano e da década -, o artigo usa o consensual ano de 1961 para demarcar uma linha de separação na produção poética portuguesa que se estende até o presente do artigo, o ano de 1990. Em 1961, ocorre o lançamento simultâneo da publicação coletiva Poesia 61 e das estréias individuais de Herberto Helder (reestréia, na verdade) e Ruy Belo. E a proposta de Nava enquanto historiador do (seu? nosso?) presente literário é que esse ciclo estaria incompleto em 1990 e incluiria, portanto, a sua própria poesia. Compartilho dessa percepção. Até mais: digo que ele continua incompleto e nos inclui no final da primeira década do século XXI. Leio em um dos nomes mais representativos e polêmicos da poesia portuguesa do século XXI, o de Manuel de Freitas, um fortíssimo argumento. Na sua poesia tanto quanto nas suas ideias. Em ambas, a sombra de Joaquim Manuel Magalhães está presente. Do Joaquim dos anos 1970. Da combativa e programática recusa à poética dos anos 1960. Escreve em um poema, Manuel: "(...) // Não gosto de Ihe chamar destino / mas houve uma espécie de sorte / nesse azar imenso (estar vivo / numa cidade indizivelmente bronca): / Dois crepúsculos que a penosa biblioteca / do liceu me fez seguir durante meses, / deixando que a cicuta e o assombro / se conformassem a 'sons e sentidos' / que não eram, nem poderia ser, os meus // (...)" (FREITAS, 2003, p. 50). A poética mais "realista" defendida por Magalhães no seu livro crítico Dois crepúsculos (1981) e na sua própria poesia encharca as páginas da poesia de Manuel de Freitas. Poeta sem qualidades é o debochado nome de uma antologia por Manuel organizada e prefaciada em tom de manifesto e em irônica provocação contra os "ourives de bairro, artesãos tardo-mallarmeanos, culturalizadores do poema digestivo, parafraseadores de luxo, limadores das arestas que a vida deveras tem" (FREITAS, 2002, p. 11). Por fim, mas não menos importante no caso de Manuel de Freitas, é ele ter escrito dois estudos sobre a poesia de Al Berto, também pertencente à geração de 1970. Daí que nosso olhar aqui será voltado para a poética de Luis Miguel Nava, principalmente como a de um corpo condensador de muitos dos debates que ocorreram e ainda ocorrem na cena poética 
portuguesa (e não só) no que respeita à experiência, referencialidade e linguagem.

\section{Repetição e diferença em cena}

Não é vontade aqui fazer a história desses debates nem da poesia desses momentos. Tarefa, aliás, já devidamente desenvolvida por outros estudiosos. Queremos tão somente pensar a poesia de Luis Miguel Nava. Suas linhas de força e alguns possíveis diálogos discursivos, não necessariamente intertextuais, com outras poéticas. Sobretudo (mas não exclusivamente) as próximas, montando um corpo poético e político que sintetiza muito das linhas de força desses anos. Da poesia de 1961, lemos um Luis Miguel ainda modernista alinhado com as poéticas neovanguardistas de ruptura, quebrando a linearidade do texto, usando formas poéticas libérrimas, mas de aguçado rigor na construção, sobretudo no domínio da sintaxe, do léxico e da construção metafórica. Esse é exemplarmente o tom de boa parte da sua estréia em Películas, de 1979. Lemos textos difíceis e auto-referentes já aos primeiros poemas, mas com boa parte dos elementos que farão parte do que chamaremos, sem muito rigor, de sua primeira fase. Provoca descontinuidades na sintaxe uma pontuação pessoal que, junto a certos procedimentos de justaposição, criam imagens cubistas, como em "(...). Da linguagem / rebentam folhas duma cor incómoda, as de que / maravilhado de água surges entre / livros, algum crime, um / menino a dissolver-se ou dele os lábios e ergues / a equívoca luz depois. (...)" ("Em Sintra", 2002, p. 38; grifo nosso). À semelhança dos títulos dos poemas no livro Morfismos, de Fiama Hasse Pais Brandão, de 1961, Luis Miguel Nava desde o início sabe que um poema é "Grafia", "Tema" e "Sincronia". Poesia 61, junto com Herberto Helder, recuperou um espírito de liberdade que depositava fé na linguagem como o espaço por excelência para encontrarmos alternativas possíveis para o mundo. O lugar por excelência, na verdade, onde se discutiam grandes problemas. A linguagem. Tornara-se ela um dos grandes mitos do século XX. Sua autonomia alcançou níveis de uso e de consciência por parte dos artistas em geral e dos escritores e poetas em particular pouquíssimas vezes vistos na história da cultura e da literatura. Está correta, portanto, a percepção de Gastão Cruz, poeta e crítico atuante a partir dessas décadas, de que a poesia de Nava "recuperou o sentido da composição e da essencialidade da linguagem que caracterizara todos os grandes poetas surgidos nos anos 40, 50 e 60 e que fora posteriormente desvalorizado ou posto em causa" (CRUZ, 2008a, p. 307). A famosa "Ars poetica" de Nava, em Películas 
- "O mar, no seu lugar pôr um relâmpago" (2002, p. 44) -, verdadeiro programa e profissão de fé na metaforização de perfil textual-surrealista, faz par mais de 10 anos depois com o famoso poema de Luiz Neto Jorge, "Magnólia", de O seu a seu tempo, livro de 1966, que diz: "A exaltação do mínimo, / e o magnífico relâmpago / do acontecimento mestre / restituem-me a forma / o meu resplendor" (1993, p. 137); diálogo que aqui se quer menos intertextual e mais de um discurso poético atento a uma "exaltação do mínimo", a um rigor construtivo e disciplina que visam à liberdade, ainda que em diferença da parte de Nava.

Diferença. Pois Nava também elaborou dicções próximas da sugestão de "realismo" ou "neo-romantismo" da década de 1970. Não nos referimos aqui à tour de force crítica e mesmo poética contra a "obscuridade" e o "hermetismo" dos poetas de 50 e 60 em Portugal, de raiz surrealizante e construtivista. Uma poética da experiência, sim, é o que vai nessa poesia que aqui interessa destacar. E na de Nava, sem dúvida. A entrar em pontos verdadeiramente obsessivos da sua poética começamos. Seu discurso não começará nem terminará nessa poética da experiência. Demais cioso e atento ao trabalho do estilo era ele para submeter-se a uma poética mais programática sem reflexão e reelaboração absolutamente pessoais. Nas décadas anteriores, essa experiência traduzia-se como experiência da linguagem e da criação. Em 1970, ganhará foros muitas vezes de tradicional referencialidade mimética. Daí o "realismo" e o "romantismo" com que Ihe tingem a face. Incorretamente, inclusive, pois assinaturas mais inventivas como as de Nuno Júdice e de Antonio Franco Alexandre aí também surgiram, exemplares artífices da linguagem poética. Malgrado sua crítica ferina, mesmo a poesia de Joaquim Manuel Magalhães não reproduz seu programa pretensamente realista, como lemos em Conseqüência do lugar, seu primeiro livro, de 1974: "Não mais verás o peixe na corrente / gastos tu e a água pelos anos / e as árvores crescendo trar-te-ão / os instrumentos da morte e do trabalho. / Acredita agora nas cortinas corridas, / nas cadeiras vazias sob os telhados / pesados de chuva (ou lágrimas serão?). [...]" (1974, p. 29). O que temos aí é principalmente a distensão da concentração metafórica no poema. Implica, essa concentração de metáforas por metro quadrado, no que Alfonso Berardinelli chama com um pouco de má vontade de "estetização do vazio" na modernidade poética, e que seria "muito mais uma lenda ideológica, mais um mito teórico-polêmico que uma realidade" (2007, p. 176-7). Ela ter-se-ia canonizado nas universidades e museus, justamente nos anos 50-60, junto com todos os experimentos e inovações de 
linguagem do alto modernismo da primeira metade do século XX. Esquecida seria, então, boa parte da poesia praticada desde sempre, inclusive por Baudelaire. Poesia discursiva e referencializável. Às vezes adotando formas como o ensaio ou a crônica em versos, o comentário político ou filosófico, a alegoria moral ou a fábula. Muito do estranhamento que a poesia de Luis Miguel Nava provoca em seus leitores treinados nas bruscas rupturas da linguagem poética moderna passa precisamente por aí. O estranhamento provocado advém da recuperação de certo tipo de referencialidade em dicção mesclada, afastada da, mas flertando com, a "poesia pura" da lírica moderna, como já vimos. Mas a sua é também claramente assentada numa tentativa de comunicar uma experiência fundamentalmente vital. Poesia vitalista com vistas a um interlocutor. E já foi apontado que a poesia portuguesa desde os anos 1970 voltou a buscar uma reaproximação com o leitor (cf. MARTELO, 2004b, p. 23759). Com Nava não foi diferente.

\section{O impulso alegórico da cena ou o "nó de pensamento"}

Recomecemos concordando com Carlos Mendes de Sousa: "a tensão na poesia de Luis Miguel Nava se gera entre duas decisivas linhas de força: a do discursivismo e imagética de Herberto Helder e a da ordenação eugeniana" (1997, p. 32). Possui um evidente impulso alegórico o trabalho de ordenar imagens em metáforas obsessivas e intercambiáveis ao longo dos textos que um livro possui, criando fortes estampas visuais. Essa vontade alegórica se caracteriza em Nava pela atuação de dois elementos que são fortes traços da sua poesia.

O primeiro é a ruptura de gêneros empreendida pela sua poesia. É poesia. Mas se realiza plenamente em textos em prosa. Intrigantes poemas em prosa. Herdeiros de Baudelaire, Mallarmé e Rimbaud, mas também dos longuíssimos versos prosaicos de Álvaro de Campos e de Herberto Helder, carregados de imagens surpreendentes, mas sugestivamente controladas e encadeadas em sua lógica, não apenas textual, mas discursiva. Sublinhará Rosa Martelo, em estudo dedicado à poesia portuguesa contemporânea, a alegoria como sendo uma das formas de expressão preferidas pelos jovens poetas portugueses (e não só). Relacionará, inclusive, muito do ceticismo e desvalorização com que pintam a atual poesia ao desprestígio moderno da alegoria diante da abstração e universalismo do símbolo romântico (cf. MARTELO, 2007, p. 83-6). Vale-se é claro dos estudos de Walter Benjamin sobre o Trauerspiel e sobre Baudelaire em perspectiva alegórica, pelo seu caráter "especulativo", "obscuro", "exemplar" e "logicista" (cf. BENJAMIN, 1985, p. 173-4). Foi Benjamin quem recuperou o valor da 
alegoria como moderna categoria interpretativa no século $X X$, sobretudo a partir da sua leitura dos poemas de As flores do mal e de $O$ spleen de Paris, de Baudelaire, das imagens que $o$ poeta francês produziu. Carregadas de imanência, concretude e exemplaridade, Benjamin lê nas figuras do flâneur, do dândi, da passante, nos olhos dos pobres, de Satã, da prostituta, do apache, da lésbica, do próprio poeta, do relógio, todos personagens dos bulevares da cidade grande, como imagens alegóricas e dialéticas do heroísmo moderno que constrói, diante da pressão reificante do capitalismo (spleen), uma experiência de memória cultural (idéal): spleen et idéal, primeira parte de As flores do mal. Muitos dos poemas - em versos ou em prosa - tratados por Benjamin são verdadeiras fábulas modernas, formas híbridas de discursividade que parecem criar um Baudelaire próximo tanto da moderna poesia abstrata, exemplarizada pelo clássico de Hugo Friedrich, Estrutura da lírica moderna, quanto do seu tempo histórico. Na verdade, o que faz Benjamin é mergulhar a poesia de Baudelaire na lógica da alegoria. O impulso alegórico de Baudelaire, visualizado figurativamente através de conceitos tratados como emblemas ou estampas alegóricas, produziram um efeito de real, um fragmento arruinado da realidade, e uma experiência compartilhada através de uma dialética de certas imagens: de um lado, a realidade frágil e dessublimada e, de outro lado, o esforço para vivê-la com sublime dignidade diante das suas ruínas (cf. MURICY, 2009, p. 221-4).

Já o efeito de real nos textos de Luis Miguel Nava é provocado por uma hábil rede metafórica. Efeito alucinatório. No entanto, ao invés dessa rede apontar para um tradicional impulso simbólico, entrevê-se nela um fortíssimo trabalho alegórico. Uma alegoria muito pessoal, é verdade, mas uma alegoria que toma o trabalho alegórico como modelo para operar pelo seu avesso. Em Nava, a alegorização caminha por uma via oposta à esperada. Ele parece partir de certos conceitos muito claros que submete a tratamentos figurativos que se desorganizarão em torno de construções imagéticas rigorosamente encadeadas, sobretudo nas suas prosas. Essas imagens

têm como resultado um trânsito desfigurador da 'Imagem' que subsume todos os modelos miméticos da ordem (da imagem do céu, da imagem da Vida, da imitação de Cristo), (...) para se colocar do lado da desordem, do lado do avesso das representações unificadoras. (SOUSA, 1997, p. 49)

Ou seja, o trabalho alegórico em Nava opera ao reverso, pelo avesso do de Baudelaire, por exemplo. O que não deixa de ser uma alegoria, mas é uma alegoria que representa a desordem, o êxtase, o esgar, o esfacelamento da vida contemporânea. Tudo muito físico, muito fortemente descrito e condensado em imagens produzidas quase em série. 
Esse discurso que pode vir tanto em versos quanto em prosa. Foi este último que preponderou e fez muito do prestígio do autor de $O$ céu sob as entranhas. A representação mimética em Nava sempre atua muito mais eficientemente pela prosa do que pela "poesia pura" da modernidade, acostumada a operações de caráter textual e simbolizante que recusam a ordem mimética. Um dos grandes achados da poesia de Nava foi conseguir conciliar tanto o espírito de ordem alegórica da representação quanto a experiência de desordem da ruptura moderna. E o seu poema em prosa é fundamental para que essa conciliação fosse possível. Ele - em suas pequenas ficções fantasmáticas, seus curtíssimos ensaios literários - ganha ares de uma alegoria ao avesso, que muito bem pode ser traduzida pelo que a crítica Silvina Rodrigues Lopes chamou de "nó de pensamento em que a ilusão e a decepção se encontram" (2003, p. 95). Um pensamento do corpo, como veremos, e que tem em títulos como "A preto e branco", "Matadouro", "Vitrines", "O secretário", "Teatro", "O grito", "A cela", alguns grandes exemplos. Leiamos, todavia, "Aliança", de Vulcão, seu último livro, de 1994:

Para quem o contemplasse, a primeira sensação era dum homem que trouxesse a roupa soterrada, mergulhada algures num poço com cujas profundezas o seu corpo tivesse estabelecido inverossímeis relações de conivência. Se alguém the pedisse, ele poderia tentar trazê-la à superfície, mas a profundidade a que se encontrava era de certa forma estrutural, constituindo assim um daqueles raros elementos sem os quais a própria noção de roupa deixa de fazer qualquer sentido, aliás tal como a de nudez, seu indissociável complemento, para cuja conformação no nosso espírito noções como a de abismo acabam por tornar-se indispensáveis. Se o fumo, ou tão-só a tênue neblina que à superfície da pele freqüentemente parece comprometer a visibilidade, mais não é sobre ela do que um rastro de emoções e sentimentos, o que outras vezes acontece é nesse espaço mais não vermos que o deserto, uma enormíssima extensão de areia refulgente perturbada aqui e além apenas por um cacto, sob cujas raízes se pressente o surdo esforço dos sentidos abraçando as profundezas. Era dessa insólita aliança dum casaco ou duma camisa com o olfacto ou a visão que a sua personalidade irradiava e, aos olhos de quem o visse a atravessar a rua, ele mais não era então do que essa faixa intercalar dum sonho à beira doutro sonho mais profundo e radical. (2002, p. 248)

Esse "nó de pensamento" é organizado pelo avesso, mas não deixa, por isso, de ser pensamento. Exemplo disso é o uso - profundamente estranhador - de conectivos de toda ordem como conjunções, preposições e dêiticos diversos. Via 
de regra, organizar o discurso é sua função, mesmo quando - diríamos, sobretudo quando - o discurso encontra-se invertido pelo uso de hipérbatos e anacolutos. Inversões textuais na sintaxe que correspondem às inversões discursivas pela alegoria ao avesso. Nó de pensamento que para ser pensamento precisa de um rigor sustentado por conectivos como "por exemplo", "se", "que", "o qual", "contudo", "tanto quanto", "quando", "não obstante", "porém", "dado que", "porque", "pois", "aí", "aqui", "é que", "de tal modo", "e assim", "é então", "só então", "seja porque", "tão pouco", "ainda", "antes", "depois", "até que ponto", etc. É aí que o texto se faz discurso e o pensamento emerge via alegoria da desordem nas metáforas e das ruínas na realidade.

O segundo traço característico do impulso alegórico na poesia de Luis Miguel Nava é a conjugação da experiência pessoal com a memória cultural implicada nesse pensamento produzido por imagens. Nava opta, todavia, pelo tratamento de paisagens naturais, ao invés da cidade baudelairiana como ponto de convergência para as suas imagens: relâmpago, mar, rio, águas, árvores, folhas, penhasco, deserto, crepúsculo, manhã, céu, noite, sol, o corpo, seus órgãos e vísceras, a pele e os ossos. Paisagens naturais que se intercambiam e criam estranhas atmosferas para o "nó de pensamento" - "O mar, no seu lugar pôr um relâmpago" ("Ars poetica"), "A substância do deserto é o mar" ("Os rostos náufragos"), "O mar está-Ihes na pele" ("Na pele"), "A pele serve de céu ao coração" ("O céu"), "O céu desembaraça-se do sangue" ("A bem dizer"), "O réptil de que somos as entranhas" ("Espinhos"), "O olhar do rapaz é às vezes a pedra" ("Há uma pedra feroz"), etc. - ou que trocam com dados culturais suas substâncias mais íntimas, chegando até a uma eliminação de fronteiras entre a percepção do dentro e do fora: "... de algum modo, então o nosso esqueleto integra o pátio, a roupa branca pendurada, a pilha de tijolos (...)" ("O uivo"), "estou como uma mesa posto até os ossos" ("O real"), "Entre a pele e o coração alçam-se as pontes" ("Manuel"), "Uma mulher encosta-se ao muro, encosta-se à memória" ("A preto e branco"), "A roupa dói-nos porque, embora / nos cubra a pele, é dentro / do espírito que estão os tecidos amarrados" ("Paisagem citadina"), "de vez em quando a roupa enfia-se-me toda para o coração" ("Washer"), "Eu mais não sou então do que um embrulho de memória, atado pelas veias e lacrado pelo espírito" ("Embrulho"). Há algo de aterrorizante nessas paisagens, o que justifica a "aproximação" que Rosa Martelo empreende do sublime na poesia de Nava (cf. MARTELO, 2004a, p. 201). Ergue-se a construção alegórica de matriz benjaminiana justamente junto desse terror sublime que podemos ver, pois calcada em imagens da moderna vivência 
individual de choque em tensão com imagens da experiência de uma memória cultural.

Sente-se pouco explorada na poesia de Luis Miguel Nava a presença tão forte da imagem do mar e, menos intensa, a do deserto. Em grande proximidade, às vezes, com a da escrita e do papel. Todos eles atravessados e atravessando, por dentro e por fora, à superfície ou nas suas profundezas, o corpo. Principalmente se pensarmos no que significam no repertório da literatura portuguesa e do seu imaginário cultural algumas dessas imagens. Nava monta um verdadeiro teatro com essas e outras imagens. Mas principalmente com essas. Um teatro que funde poderosas sensações corporais de choque com a memória que o próprio corpo carrega consigo e que é permanentemente reelaborada. E vemos o corpo assumir o papel de teatro alegórico do drama dessas experiências. Teatro dialético, pois que repleto de imagens sublimes que purificam a vida e de imagens de choque que a banalizam. Leiamos, justamente, "Teatro", do livro Rebentação, de 1984:

Na selva dos meus órgãos, sobre a qual foi desde sempre a pele o firmamento, ao coração coube o papel de rei da criação.

Ignoro de que peça é todo este meu corpo a encenação perversa, onde se vê o sangue rebentar contra os rochedos.

Do inferno, aonde às vezes o sol vai buscar as chamas, sobre ele impiedosamente jorram os refletores (2002, p. 145).

O corpo não só é imagem como também é suporte alegórico, moderno e antigo, para que outras imagens possam vir colar-se a ele e adquirir vida.

\section{Entreato: encenação política no corpo}

Da percepção do corpo individual à sensação de pertencimento coletivo a um corpo sócio-político, Foucault afirma que "o grande fantasma é a idéia de um corpo social constituído pela universalidade das vontades. Ora, não é o consenso que faz surgir o corpo social, mas a materialidade do poder se exercendo sobre o próprio corpo dos indivíduos" (FOUCAULT, 1995, P. 146). O filósofo parece apontar a constituição das metáforas tão correntes de corpo social e de corpo político para representar o conjunto das diversas instituições - 
fantasmáticas - mas eficientíssimas no exercício do seu poder sobre as singularidades - individuais ou não. De um lado, "a materialidade do poder" se exerce sobre os corpos para a constituição das diversas instituições sociais, históricas e políticas que formalizarão uma memória cultural e uma "idéia [fantasmática] de um corpo social" homogeneamente compartilhado. De outro lado, no entanto, é precisamente pela observação e cuidado com o corpo que encontramos um espaço, não apenas de resistência, mas de subjetivações que lutam por reelaborar essas metáforas de corpo social e político e de atenção à memória das diferenças sócio-históricas - referimo-nos ao tema greco-latino do "cuidado de si", desenvolvido por Foucault no terceiro volume da sua História da Sexualidade.

Jacques Le Goff flagra na Idade Média essa ambivalência do corpo (como deflagrador de sentidos coletivos institucionais e alternativos), quando ele é central na manifestação de dois poderosos eventos da cultura no período: a Quaresma e o Carnaval. A primeira entendida como um instrumento da lógica cristã para controlar o corpo e conseguir melhor ordenar pelo calendário os gestos e movimentos de toda a coletividade - desde as camadas populares até o Rei e os destinos do Reino. A segunda, como manifestação originariamente pagã, que cultiva o corpo como agente de afirmação da vida do corpo e da fertilidade da terra, contra o controle eclesiástico (cf. LE GOFF, 2003, p. 61-5). Mas é na doutrina teológico-política medieval dos Dois Corpos do Rei, descrita por Ernst Kantorowitz (cf. 1998), que visualizamos com mais clareza o corpo como agenciador de plasticidade política e de força transcendente, sobretudo o corpo do Rei. No contexto da tensão religiosa reformista, a figura do Rei foi aproximada à do Papa e ambas tiveram como modelo analógico a teoria das Duas Naturezas de Cristo - entendido como Deus e como homem ao mesmo tempo: Cristo como Deus-homem. Isso trouxe fortes desdobramentos jurídicos para o conceito de Estado Absoluto e, por extensão, para a presença dos membros do Estado, como nobres, clero, administradores e soldados de vários níveis. É a partir dessa idéia da atuação dos membros do Estado que podemos juntar à doutrina dos Dois Corpos a reflexão de Norbert Elias em $O$ processo civilizador (cf. 1993), de que os sujeitos políticos sofisticaram no fim do Medievo o controle social sobre seus corpos enquanto autocontrole e forma de "civilizar" o corpo, sua presença e vida pública, sobretudo no ambiente social da corte.

Devemos entender todos esses corpos próximos à noção espinosiana de corpo que Gilles Deleuze e Judith Butler cuidadosamente desenvolvem para defini-lo 
como "um campo de força" (DELEUZE, 1962, p. 45) e como "um conjunto de fronteiras, individuais e sociais, politicamente significadas e mantidas" (BUTLER, 2003, p. 59). Esse perfil agonístico do corpo é encontrado justamente quando avaliamos a produtividade de uma poesia como a de Luis de Camões, que freqüentou como poeta a corte lisboeta do século XVI, compartilhando das suas pedagogias e modos de subjetivação na sua lírica, bem como dando configuração e justificação retórico-letrada às expansões políticas na sua épica. A ode "Aquele moço fero" explora bem a ambivalência moral do/sobre o corpo:

Aquele moço fero

Na peletrônia cova doutrinado

Do Centauro severo,

Cujo peito esforçado

Com tutanos de tigre foi criado;

$\mathrm{Na}$ água fatal, menino

O lava a mãe, pressaga do futuro,

Para que ferro fino

Não passe o peito duro

Que de si mesmo a si se tem por muro.

A carne the endurece,

Que ser não possa de armas ofendida.

Cega! Que não conhece

Que pode haver ferida

$\mathrm{Na}$ alma, que menos dói perder a vida!

(...) (CAMÕES, 2003, p. 329).

Aludindo ao mito de Aquiles, o sujeito lírico desconhece a força do amor e, por isso, tem seu valor investido sobre seu adestramento como homem político, isto é, como soldado. Dividido entre o controle através da figura institucional da mãe, que o forma para a vida pública, e a pulsão erótica do sujeito amoroso, o vencido de amor, pois "que não conhece / que pode haver ferida / que menos dói perder a vida", o sujeito é constituído dúplice pela própria duplicidade do seu corpo: de um lado, braço forte do corpo político do Estado, "peito duro / que de si a si mesmo tem por muro", em exemplo de internalização do controle social, como demonstrado por Elias; de outro lado, maleável diante da força da pulsão amorosa, capaz de doer mais do que a morte do corpo. Continua o sujeito, mais 
adiante, sua saga civilizatória entre a ordem política e a erótica: "Ali se viu cativo / Da cativa gentil que serve e adora; / Ali se viu que, vivo, / Em vivo fogo mora, / Porque de seu senhor se vê senhora. / (...)" (CAMÕES, 2003, p. 330). À parte a mesma tópica da famosa redondilha $A$ uma cativa chamada Bárbara, o que lemos é que o corpo político do jovem guerreiro, moldado pelos códigos que controlam o espaço de convívio das relações públicas e do Estado Absoluto que tem o Rei como cabeça e topo da hierarquia - não resiste a outra força que se lhe exerce. Camões, na sua lírica amorosa apontada como dialética e partida entre a Laura idealista-cristã de Petrarca e a Vênus empírico-erótica dos pagãos, sugere a inevitabilidade da divisão desses jovens e fortes corpos políticos por outros códigos, aqueles formados pelos corpos eróticos, cativos da experiência direta da paixão ("doutos corações não são de ferro"). E conclui o poema afirmando a subjetivação amorosa como "mais conveniente / e conforme":

Já foge de onde habita;

Já paga a culpa enorme com desterro.

Mas oh! grande desdita!

Bem mostra tamanho erro

Que doutos corações não são de ferro.

Antes na altiva mente,

No sutil sangue e engenho mais perfeito,

Há mais conveniente

E conforme sujeito

Onde se imprima o doce e brando afeito. (CAMÕES, 2003, p. 331)

No ensaio de Jorge Fernandes da Silveira, "Sem as pe(r)nas do povo, o real e a análise - Camões entre dois pontos: o crítico (Saraiva) e o poético (Cesário)", o sujeito d'Os Lusíadas é o "peito ilustre lusitano", anunciado na sua Proposição; logo, afirmamos nós, seu sujeito épico é o corpo social e político do reino português: social porque coletivo, político porque canta "as memórias gloriosas / Daqueles Reis que foram dilatando / A Fé, o Império" (I, 2). Afirma Jorge, repetindo Saraiva, que o concerto da subjetividade no mundo à época de Camões dar-se-ia por um amor dúplice: amor coletivo, entre "as armas e o os barões assinalados", e amor individual, o amor ardente do seu lirismo. Assim, tal qual o lírico, o épico. O amor ardente em Os Lusíadas encontrar-se-ia justamente nas subjetividades amorosas caladas pela poderosa "identidade 
formal, (...), imagem do caráter uno da personagem principal do poema, o povo português" (SILVEIRA, 2007, p. 17): o corpo político do Estado Monárquico Português. Inês, Adamastor e a presença do Poeta nos seus excursos, como corpos cujas vozes apaixonadas são rasuradas, figuram apenas como as contrapartes necessárias à expansão e à guerra. O dístico épico do 'Amor e Guerra' só valeria no poema para fazer prevalecer o segundo, para forjar homens públicos como o sujeito lírico que a mãe, na ode anteriormente lida, habilmente molda, guerreiros de subjetividade cruzadístico-feudal, segundo uma das teses de Saraiva, que Jorge habilmente desconstrói (cf. SILVEIRA, 2008, p. 17-8).

É fundamental, no entanto, não esquecer que, n'Os Lusíadas, Camões ecoa a voz do poeta também como assujeitada pela aparelhagem do Estado. Durante todo o texto há esse posicionamento tenso entre narração e autor-narrador, com o segundo contando uma história que o "oculta" como (para muitos, o verdadeiro) herói do poema, junto a Inês e ao Adamastor - corpos supliciados, memória rasurada. Talvez não houvesse como ser diferente, se pensarmos na violência instituinte dos imaginários sócio-políticos nacionais, que buscam se erigir a partir do sacrifício de vítimas usadas como bodes expiatórios. O corpo político e o amor coletivo necessitavam, então, constituir-se naquele momento de afirmação da nacionalidade pela expansão imperial e religiosa. Mas Camões, todavia, logra manter viva pelo lirismo amoroso - também presente no épico guerreiro a memória dos corpos apaixonados, dos peitos que ardem um amor também político, na verdade micropolítico. O amor de Inês e Pedro, vencido pela Razão de Estado: "Traziamna os horríficos algozes / Ante o Rei, já movido a piedade; / Mas o povo, com falsas e ferozes / Razões, à morte crua o persuade." (III, 124); o amor do Adamastor, vencido pelo enigma da paixão e por contá-lo ao Gama:"Qual será o amor bastante / De Ninfa, que sustente o dum gigante?" $(\mathrm{V}, 53)$; e o amor do Poeta pela Musa, oposto ao amor à coletividade política: "No mais, Musa, no mais, que a Lira tenho / Destemperada e a voz enrouquecida, / E não do canto, mas de ver que venho / Cantar a gente surda e endurecida" $(X, 145)$.

Tomamos o corpo como esse lugar onde se disputam batalhas e se exercem forças diversas - discursivas, subjetivas, sociais e políticas. Todo gesto escrito também deve ser considerado um ato de força discursiva de um corpo que produz as subjetividades que irão informá-lo enquanto corpo individual e político. A poesia de Luis Miguel Nava é um campo privilegiado da escrita para a análise e produção desses processos de subjetivação que implicam os corpos e que a memória da força política sobre eles ganha um outro tipo de visibilidade. Nela são atritados posicionamentos em que parece se destacar uma subjetividade cujo corpo historicamente é mantido sob observação e controle, à 
margem das poderosas máquinas mnemônicas dos Estados Nacionais: no caso português, corpos controversos, porque camonianamente erotizados, mas também ambíguos com relação ao próprio modelo épico camoniano, de modelo bélico-estatal.

\section{Cenas da memória}

Camões cuidou para que o corpo político do Estado português ganhasse sentido também fora de suas fronteiras, fora de sua superfície geográfica. Apesar de "Cortando vão as naus a larga via / Do mar ingente para a pátria amada", na profundidade do mundo descoberto abriu-se também a profundidade da perspectiva e do olhar do outro. Depois veremos isso. Exatamente em Nava. Até lá, todavia, o que se construiu foi um corpo político que se expandiu da terra para o mar, que se Ihe fez extensão geopolítica e corpórea. O mar ganhou dono, ganhou adjetivo, ganhou sobrenome. Mar português. Viver como autêntico português era viver fora de suas fronteiras, como afirma o Padre Antonio Vieira no Sermão de Santo Antonio pregado em Roma, na Igreja de Santo Antonio dos Portugueses, no ano de 1670, no contexto da Pós-Restauração Joanina, após o desaparecimento do corpo de D. Sebastião nas areias do deserto marroquino. Ou seja, Corpo político, Mar, Deserto e Independência parecem encenar um grande teatro dos destinos lusitanos. E que Luis Miguel Nava retoma em vários de seus poemas, articulando-os à sua vivência mais íntima e intransferível. Leiamos "Os rostos náufragos", do livro O céu sob as entranhas, de 1989:

A substância do deserto é o mar, que dele difere apenas pelo grau de apuramento. 0 mar surge no termo dum processo em que o deserto é uma das fases ou, mais concretamente, a sua cristalização. Se se atender a que o lugar onde esse apuramento se produz é o nosso espírito, não poderão causar qualquer estranheza factos como, por exemplo, o de a presença do deserto ser notada por quem, como os marinheiros, tenha um íntimo contacto com o mar.

O que eu do mar conheço, devo-o contudo, mais do que qualquer outra experiência, a corpos onde a nitidez das águas ultrapassa muitas vezes a dos próprios traços fisionômicos; não raro, basta uma breve carícia, ou outro contacto ainda mais discreto, para sentir como são avassaladoras essas águas, à superfície das quais parecem prestes a afundar-se os rostos náufragos.

Não obstante, também já eu me apercebi da clandestina presença do deserto, o que me leva a compará-lo àquela roupa que persiste em irromper na pele de quem por isso nunca por completo se consegue desnudar. (2002, p. 159) 
O mar está para o deserto como o deserto está para o tecido da pele. E o mar de Nava não é o mar dos conquistadores. É o mar de quem é conquistado pela experiência carinhosa com outros corpos. Essa experiência desorganiza pela violência das ondas, da maré, da rebentação (título de um livro seu) que explodem (em) seu corpo. E o desorganizam como às alegorias que são montadas pelo avesso. Expor-se ao mar, para Nava, é expor-se à mudança:

"(...) o homem que nos barcos sobe à gávea o faz para perscrutar a sua própria pele, obter dela uma outra perspectiva" ("Na gávea"; 2002, p. 108). Mudança que é desejada imensamente, mas nunca pacífica, pois consigo traz a memória. Mar, corpo e memória confundidos num único flash que pipoca nas mãos do poeta: como "O mar está-nos no corpo" ("O rei"; 2002, p. 136), também "... o mar por onde deflagram / as ondas por ação da memória" (sem título; 2002, p. 75). Mas é nos rapazes que Luis Miguel Nava melhor trabalha o encontro do mar com o corpo. É nos rapazes que melhor se projeta um encontro entre experiência cultural e vivência pessoal. Pois é nos rapazes que uma memória cultural ganha profundidade e perspectiva: "O mar, venho ver-Ihe a pele a rebentar / ao longo das falésias, o que sempre / me traz a exaltação desses rapazes que circulam / por Lisboa no verão. / O mar está-Ihes na pele. Partilho / com eles os quartos das pensões, sentindo as ondas / a avançar entre os lençóis. Perco-me à vista / da pedra onde o mar vem largar a pele" ("Na pele"; Nava, 2002, p. 95). O desejo por corpos do mesmo sexo, o desejo homoerótico, encenado e alegorizado em Luis Miguel Nava. O jogo entre rapazes, marés, pedras, pele e memória. A reconstrução de uma memória cultural portuguesa de matriz guerreira, em que a virilidade do corpo masculino espelhava no e era espelhada pelo Corpo Político do Estado Imperial Português. Corpo viril. Estado guerreiro. Espírito católico. O macho divinizado como modelo dos modernos EstadosNação também. Corpos burgueses. Ainda antes, os duelos na transição do Medievo para a Modernidade simbolizavam essa associação entre corpo, honra, coragem, território, militarização, nacionalismo e transcendência (cf. OLIVEIRA, 2004, p. 23-31). Mas Nava sabia que quando o corpo masculino passa a ser objeto de desejo de um olhar masculino, o próprio corpo político se reelabora e a memória (do mar) que nos vai à pele ganha novas cores. E espalhou seu desejo homoeroticamente pelo mar e pela pele dos rapazes que amou: "... o mar, sentindo às mãos desse rapaz uma janela abrir como um sorriso. // ... a língua a interpelar-Ihe a pele. // a pele, sentindo ao fundo / de cada poro seu o mar rebentar" (sem título; 2002, p. 73).

As "imagens em movimento" (SOUSA, 1997, 34) nos poemas de Nava não abstraem a paisagem. Ao contrário de retomar a figurativização, entretanto, elas aproximam-se por vezes do que Gilles Deleuze viu na pintura de Francis Bacon - sobre o qual Nava escreveu um belo artigo - como Figura. São imagens em movimento que constroem uma Figura (alegórica?) que não representa nada do mundo, mas encarna as intensidades que atravessam as vivências. Ao 
colocar em movimento de intercâmbio as Figuras do Mar, do Deserto, da Árvore, da Rebentação, das Pedras, dos Rapazes, da Pele, dos Órgãos Viscerais, das Folhas, do Osso, do Prego, do Muro, do Polvo, etc., Nava ativa um tipo de vivência pessoal em tensão com a experiência cultural, sem necessariamente escrever uma poesia narrativa no sentido fraco, uma poesia que representa um mundo anterior às suas potências inventivas. Ao contrário: as "imagens em movimento" criam uma Figura, atêm-se ao fato. Todos os encadeamentos discursivos do texto servem de função tátil ou háptica (cf. DELEUZE, 2007, p. 15), que indicam o mundo - não desejam simplesmente narrá-lo - da Figura construída no poema. Fala-se de uma "hapticização do mundo" na poesia de Luis Miguel Nava: "tudo é olhado como se fosse ferido ou como se com esse olhar se fizessem feridas" (SOUSA, 1997, p. 40). Quem fere quem? Quem toca quem? O quadro ao olhar ou vice-versa? Essa ambivalência é possível graças a um deslocamento condensador da poesia de Nava em relação às poéticas dos anos 1960, de maior desreferencialização, e a dos anos 1970, de maior referencialização. Queremos sublinhar, no entanto, que essas Figuras em movimento de "hapticização do mundo" agem principalmente para construção e aí está sua grande força como poeta - de corpo que agencia vivência pessoal e experiência cultural. É sempre um corpo que está em cena na poesia de Luis Miguel Nava. Um corpo que se faz (de) memória pessoal e coletiva simultaneamente. Corpo-mar. Corpo-deserto. Corpo-rebentação. CorpoFolhagem. Corpo-pele. Corpo-carne. Corpo-vísceras. Corpo-escrita.

\section{Cenas da escrita}

Não o exime do dilaceramento, a centralidade do corpo na poesia de Luis Miguel Nava. Ao contrário. Sua posição ressalta a ferida - sua e do mundo compartilhada. Compartilhada porque à superfície. Toda ferida é uma passagem entre o dentro e o fora: "Agradou-Ihe a idéia (...) de que pudesse homogeneizar o exterior e o interior (...) por uma progressiva porosidade do seu corpo, ou pelo menos um corpo exterior" ("Insônia"; 2002, p. 164). Uma ferida compartilhada não é uma ferida desejada, mas uma ferida necessária. Sentida. Ferida interseccionista. E que se aproxima bastante nele do próprio ato de escrever, pois "escrever é, para mim, tentar desfazer nós, embora o que na realidade acabo sempre por fazer seja embrulhar ainda mais os fios" ("Os nós da escrita; 2002, p. 104). São esses os "nós" de uma experiência cultural sobredeterminada que organiza corpo e organismo. Dando-lhes o violento nó da nacionalidade ou da heterossexualidade, por exemplos. Escrever para Nava é tentar desfazer esses "nós", esses blocos de coletividades históricas que pouco o 
conectam com sua experiência contemporânea. Sem jogá-los simplesmente fora, Nava reelabora esses nós, os reembrulha em outros formatos, reembrulhase também em novos corpos, dá-lhes novos sentidos, desenhando - assim novas imagens de uma experiência que não seja apenas pessoal, mas que ganhe a marca da memória cultural.

Mas esse é um empreendimento de força e, às vezes, violência contra si próprio. A exemplo de Artaud, lutar contra si, para lutar contra o céu - "o céu encurvanos a carne" ("Naufrágio"; 2002, p. 194) - para acabar com o julgamento de deus. Acabar com os moralismos que sustentam as antigas experiências, sem acabar com as experiências. Por isso a escrita e a ferida. Por isso a violência e o erotismo. Por isso o espacejamento do corpo, porque

Perdia-se-Ihe o corpo no deserto, que dentro dele aos poucos conquistava um espaço cada vez maior, novos contornos, novas posições, e lhe envolvia os órgãos que, isolados nas areias, adquiriam uma reverberação particular. Ia-se de dia para dia espacejando. As várias partes de que só por abstração se chegava à noção de um todo começavam a afastar-se umas das outras, de forma que entre elas não tardou que espumejassem as marés e a própria via-láctea principiasse a abrir caminho. A sua carne exerce aliás uma enigmática atracção sobre as estrelas, que em breve conseguiu assimilar, exibindo-as, aos olhos de quem o não soubesse, como luminosas cicatrizes cujo brilho transmutado em sangue, lentamente se esvaía. Ele mais não era, nessas ocasiões, do que um morrão, nas cinzas do qual, quase imperceptível, se podia no entanto detectar ainda a palpitação das vísceras, que a mais pequena alteração na direç̧ão do vento era capaz de pôr de novo para funcionar. Resolveu então plastificar-se. Principiou pelas extremidades, pelos dedos das mãos e pelos pés, mas passado pouco tempo eram já os pulmões, os intestinos e o coração que minuciosamente ele embrulhava em celofane, contra o qual as ondas produziam um ruído aterrador. (2002, p. 166)

Os textos de Luis Miguel Nava são alegorias porque são feitos das ruínas da história cultural portuguesa. O corpo eviscerado, aberto, dissecado, plastificado na sua poesia é o corpo histórico dessa memória. Corpo político. Mas também corpo vivido. Corpo ferido - "o meu corpo divide-se entre a História e a atmosfera" ("Outro rio", 2002, p. 195). Pois que escreve sua vivência e a alegoriza enquanto experiência cultural. E vice-versa. Escrita compartilhada. Como se compartilha a ferida entre dentro e fora, entre corpo e mundo. A escrita é o gesto, o método de compartilhamento preferido. Por ela o corpo desorganizado reordena-se através de um erotismo muito pessoal e muito 
poderoso - "Eu amo assim: com as mãos, os intestinos. Onde ver deita folhas" (2002, p. 43), famosa "Ars erotica" do primeiro livro, Películas, de 1979, que espelha todo o intenso amálgama de amor e crueldade presente na sua escrita. Mesmo quando, nos últimos livros, sua visão deita menos folhas e torna-se menos luminosa, menos relampejante, menos cheia de rapazes, e mais noturna, mais fatal, assumindo uma consciência trágica: "Corroem-se as entranhas se preciso / for, neste areal, que as vísceras / de deus se façam coroar. // A trágica circunferência / traçada no veludo empresta a cada / momento do passado uma eficácia atroz" ("Três voltas"; 2002, p. 215). Violência que em Vulcão assume ares de "temática obsessiva", como afirma Gastão Cruz (2008b, p. 323). O sangue passa a ser cada vez mais importante na sua escrita, na sua potencial ferida de tendência hemofílica. Sangue que desperta a crueldade e faz parte de uma possível encenação ritual da vida, que em "Matadouro" parece ter uma espécie de ápice:

Dancei num matadouro, como se o sangue de todos os animais que à minha volta pendiam degolados fosse o meu. Dancei até que em mim houvesse espaço para um poema de que todas as imagens depois fossem desertando. (...) (2002, p. 181)

\section{Referências bibliográficas:}

BENJAMIN, W. Origine du drame baroque allemand. Paris: Flammarion, 1985.

BERARDINELLI, A. Poesia e gênero lírico: vicissitudes pós-modernas. Da poesia à prosa. São Paulo: Cosac Naify, 2007, p. 175-190.

BUTLER, J. Problemas de gênero. Rio de Janeiro: Civilização Brasileira, 2003.

CAMÕES, L. V. de. Obra completa. Rio de Janeiro: Nova Aguilar, 2003.

CRUZ, G. Luis Miguel Nava: o corpo vulnerável. A vida da poesia. Textos críticos reunidos. Lisboa: Assírio e Alvim, 2008a, p. 307-309.

CRUZ, G. Imagem do paraíso e luz negra na vida e na poesia de Luis Miguel Nava. A vida da poesia. Textos críticos reunidos. Lisboa: Assírio e Alvim, 2008b, p. 321-6.

DELEUZE, G. Nietzsche et la philosophie. Paris: PUF, 1962.

DELEUZE, G. Francis Bacon. A lógica da sensação. Rio de Janeiro: Jorge Zahar, 2007.

ELIAS, N. O processo civilizador I. Rio de Janeiro: Jorge Zahar, 1993.

FOUCAULT, M. Poder-corpo. Microfísica do poder. Rio de Janeiro: Graal, 1979. 
FREITAS, M. de (org.). Poetas sem qualidades. Lisboa: Averno, 2002.

FREITAS, M. de. Beau séjour. Lisboa: Assírio e Alvim, 2003.

JAMESON, F. Pós-modernismo ou a lógica cultural do capitalismo tardio. São Paulo: Ática, 1996.

JORGE, L. N. Poesia. Lisboa: Dom Quixote, 1993.

KANTOROWITZ, E. Os dois corpos do rei. São Paulo: Companhia das Letras, 1998.

LE GOFF, J., TRUONG, N. Une histoire du corps au Moyen Âge. Paris: Liana Levi, 2003.

LOPES, S. R. Representações face ao irrespirável. Exercícios de aproximação. Lisboa: Vendaval, 2003.

MAGALHÃES, J. M. Conseqüência do lugar. Lisboa: Moraes Editores, 1974.

MARTELO, R. M. Aproximações ao sublime na poesia de Luis Miguel Nava. Em parte incerta. Estudos de poesia portuguesa moderna e contemporânea. Porto: Campo das Letras, 2004a, p. 201-210.

MARTELO, R. M. Reencontrar o leitor: alguns lugares da poesia contemporânea. Em parte incerta. Estudos de poesia portuguesa moderna e contemporânea. Porto: Campo das Letras, 2004b, p. 237-259.

MARTELO, R. M. Veladas transparências (o olhar do alegorista). Vidro do mesmo vidro. Tensões e deslocamentos na poesia portuguesa depois de 1961. Porto: Campo das Letras, 2007, p. 81-105.

MURICY, K. Alegorias da dialética: imagem e pensamento em Walter Benjamin. $2^{a}$ ed. Rio de Janeiro: Nau, 2009.

NAVA, L. M. Poesia completa (1979-1994). Lisboa: Dom Quixote, 2002.

NAVA, L. M. Ensaios reunidos. Lisboa: Assírio e Alvim, 2004.

OLIVEIRA, P. P. de. Macho divinizado. A construção social da masculinidade. Belo Horizonte: EDUFMG; Rio de Janeiro, IUPERJ, 2004, p. 19-82.

SOUSA, C. M. de. A coroação das vísceras. Relâmpago. Revista de poesia. Lisboa: Fundação Luis Miguel Nava, $n^{\circ} 1$, out, 1997, p. 31-55.

SILVEIRA, J. F. da. Sem as pe(r)nas do povo, o real e a análise - Camões entre dois pontos: o crítico (Saraiva) e o poético (Cesário). o Tejo é um rio controverso. Rio de Janeiro: 7 Letras, 2008, p. 13-36.

Title: 
The "thought knot" of Luis Miguel Nava. Scenes, allegories, bodies and memories

\section{Abstract:}

A reading of the Portuguese Poet Luis Miguel Nava (1957-1995) as of a hypothesis grounded on the idea of Nava's poetical speech as convergence of the abstract-experimental trend of the sixties and mimetical-referencial of the seventies, a powerfully personal synthesis, that articulates these esthetical contexts of the Portuguese poetry to concepts such as allegory and cultural experience and memory.

\section{Keywords:}

Luis Miguel Nava, Allegory, Body, Cultural experience, Contemporaneous Portuguese Poetry 